\title{
ANALISIS KEUNGGULAN KOMPARATIF DAN KOMPETITIF USAHA TERNAK AYAM RAS PEDAGING DI KECAMATAN MUSUK KABUPATEN BOYOLALI
}

\author{
Anisah Eka Mutmainah, Tinjung Mary Prihtanti \\ Program Studi Agribisnis, Fakultas Pertanian dan Bisnis, Universitas Kristen Satya Wacana \\ Jalan Diponegoro 52-60 Salatiga - Indonesia 50711 Telp. (0298) 321212 \\ E-mail : 522013063@student.uksw.edu
}

\begin{abstract}
This Research analyzed that comparative advantage and competitive of broiler chicken's livestock business in Musuk Subdistrict of Boyolali Regency. For sampling uses a Saturated Sampling technique (census method) by taking all available samples as many thirty-two sample of broiler's breeder around Musuk Subdistrict. To analyzed chicken livestock business uses Policy Analysis Matrik (PAM) and Ms. Excel as analysis tools. The result of this research shows that PCR (Private Cost Ratio) value $<1$ is 0,63 that means the commodity system of broiler chicken which is cultivated by breeder has a small competitive advantage. In addition to defraying domestic factor at private price, breeders are also able to compete with broiler chickens livestock business in other region. A commodity has a comparative advantage if it has DRCR (Domestic Resources Cost Ratio) value <1, the meaning is the profit obtained by the breeder is grater than the cost of social input non tradable. In case of broiler chickens in Musuk Subdistrict obtained grade DRCR $<1$ is 0,95 that means livestock business produced has comparative competitiveness because it is able to finance domestic factors at social prices and is economically efficient.
\end{abstract}

Keywords: Broiler Chicken, Comparative Advantage, Competitive Advantage, Policy Analysis Matrik (PAM),

\begin{abstract}
Abstrak: Penelitian ini bertujuan untuk menganalisis keunggulan komparatif dan kompetitif usaha ternak ayam ras pedaging, di Kecamatan Musuk Kabupaten Boyolali. Pengambilan sampel yang digunakan dengan menggunakan teknik sampling jenuh (metode sensus) dengan mengambil seluruh sampel yang ada sebanyak 32 sampel peternak ayam ras pedaging di seluruh Kecamatan Musuk, untuk alat analisisnya menggunakan Policy Analysis Matrik (PAM). Hasil analisis diperoleh nilai PCR (Private Cost Ratio) <1 yaitu 0,63 yang artinya sistem usaha ternak ayam ras pedaging yang diusahakan oleh peternak memiliki keunggulan kompetitif. Selain mampu membiayai faktor domestik pada harga privat, peternak juga mampu bersaing dengan usaha ternak ayam ras pedaging diwilayah lain. Usaha ternak memiliki keunggulan komparatif apabila memiliki nilai DRCR (Domestic Resources Cost Ratio) $<1$, artinya keuntungan yang diperoleh peternak lebih besar dibanding biaya input non tradable sosialnya. Pada kasus ayam ras pedaging di Kecamatan Musuk diperoleh nilai DRCR $<1$ yaitu 0,95 yang artinya usaha ternak yang dihasilkan memiliki daya saing komparatif karena mampu membiayai faktor domestik pada harga sosial dan efisien secara ekonomi.
\end{abstract}

Kata kunci: Ayam Ras Pedaging, Keunggulan Komparatif, Keunggulan Kompetitif, Policy Analysis Matrik (PAM) 


\section{PENDAHULUAN}

Salah satu jenis ayam ras yang populer dibudidayakan masyarakat adalah ternak ayam ras pedaging. Permintaan akan daging ayam sebagai penyedia protein hewani semakin besar, terbukti saat ini daging ayam merupakan penyumbang terbesar terhadap produksi dan konsumsi daging di Indonesia. Produksi daging ayam dalam negeri tahun 2018 sebesar 3.565.495 ton sedangkan kebutuhan konsumsi sebesar 3.047.676 ton di penuhi dari ayam potong sebanyak 51 persen dan konsumsi daging sebesar 11,5 kilogram/orang/tahun dan jumlah penduduk sekitar 265 juta orang dipenuhi dari daging ayam sebanyak 49 persen.

Namun di sisi lain industri ayam ras pedaging masih memiliki permasalahan permasalahan di berbagai subsektor agribisnis yang akan berpengaruh negatif terhadap daya saing. Pada subsektor hulu, permasalahan terkait penyediaan pakan menjadi isu yang sangat menonjol. Sebagian besar bahan baku pakan masih sangat tergantung pada impor, seperti impor jagung yang mencapai 40-50 persen; bungkil kedelai 95 persen; tepung ikan 90-92 persen; tepung tulang dan vitamin/ feed additive hampir 100 persen impor. Jagung merupakan komponen utama pakan ayam ras pedaging. Negara-negara yang memiliki daya saing tinggi sangat tergantung pada pasokan jagung domestik. Ketergantungan terhadap impor jagung sangat merugikan bagi Indonesia karena pasokan untuk pakan (feed) semakin berkurang akibat persaingan dengan kebutuhan untuk pangan (food) dan bahan bakar nabati (fuel). Keadaan ini menyebabkan kecenderungan harga pakan yang terus meningkat. Padahal alokasi biaya untuk pakan merupakan yang terbesar, sekitar 60-70 persen dari biaya produksi. Dengan meningkatnya harga pakan, biaya produksi daging ayam ras secara otomatis juga akan meningkat. Pernyataan tersebut menjadi kontradiktif apabila benar - benar diterapkannya menurut UU No 18 tahun 2012 pasal 36 ayat 1 menjelaskan untuk impor pakan ternak hanya akan dilakukan apabila produksi pakan dalam negeri tidak mencukupi dan/ atau tidak dapat diproduksi didalam negeri.

Kebijakan pemerintah yang terkait pengembangan industri ayam ras pedaging dimulai pada tahun 1970 melalui kebijakan penanaman modal asing (PMA). Pada tahun tersebut disetujui pengembangan pembibitan ayam ras dari Negara Jepang dan Amerika Serikat. Kebijakan ini disusul dengan kebijakan budidaya tahun 1980 yang mengatur pembatasan skala usaha ayam ras pedaging. Tujuan kebijakan tersebut adalah untuk menyediakan lapangan sebanyak - banyaknya bagi rakyat dengan Undang - Undang Peternakan No 18 Tahun 2009.

Kabupaten Boyolali memiliki 19 Kecamatan yang sekarang ini sedang berusaha keras meningkatkan budidaya ayam ras pedaging, selaras dengan kondisi tersebut, bahwa komoditas ternak ayam ras memiliki nilai ekonomi yang cukup potensial serta adanya permintaan produksi dan konsumsi daging ayam yang semakin meningkat, didukung pula dengan peningkatan pertumbuhan populasi ayam ras pedaging, maka peneliti ingin mengetahui bagaimana keunggulan komparatif dan kompetitif yang terjadi pada usaha ternak ayam ras pedaging di Kecamatan Musuk, Kabupaten Boyolali.

Penelitian ini juga mengacu pada penelitian terdahulu dari Krisna, et al. (2014) dengan judul Analisis Daya Saing Komoditas Kelapa di Kabupaten Kupang, penelitian dari Angga, et al. (2014) dengan judul Keunggulan Kompetitif dan Komparatif Usahatani Manggis di Kecamatan Tanggamus serta penelitian dari Dhiany, S.A. dengan judul skripsi Analisis Daya Saing Usaha Tani Mangga Gedong Gincu (Mangifera indica L.) Kasus di Desa Sliyeg Lor, Kecamatan Sliyeg, Kabupaten Indramayu, Jawa Barat (2008).

\section{METODE PENELITIAN}

Penelitian ini dilaksanakan pada bulan Agustus - September 2017 di Kecamatan Musuk, Kabupaten Boyolali, Jawa Tengah. Pemilihan lokasi ini dilakukan secara sengaja (Purposive) dengan pertimbangan bahwa lokasi tersebut merupakan salah satu sentra produksi ayam ras pedaging di Kabupaten Boyolali.

Sampel penelitian dipilih secara sampling jenuh (metode sensus) artinya teknik penentuan sampel bila semua anggota populasi digunakan sebagai sampel. (Sugiyono, 2002). Jumlah sampel yang diambil dalam penelitian ini adalah seluruh peternak yang berada di Kecamatan Musuk sebanyak 32 sampel. 
Teknik analisis data yang digunakan dengan metode PAM (Policy Analysis Matrix) yang telah kembangkan oleh Monke dan Pearson sejak tahun 1987. Oleh sebab itu metode dalam penelitian ini adalah pendekatan keunggulan kompetitif dan komparitif model PAM dengan formulasi seperti pada Tabel 1.

Tabel 1. Konstruksi Model Policy Analysis Matrix

\begin{tabular}{|c|c|c|c|c|}
\hline \multirow[b]{2}{*}{ Keterangan } & \multirow[b]{2}{*}{ Penerimaan } & \multicolumn{2}{|c|}{ Biaya } & \multirow[b]{2}{*}{$\begin{array}{c}\text { Keuntu- } \\
\text { ngan }\end{array}$} \\
\hline & & $\begin{array}{c}\text { Input } \\
\text { Tradable }\end{array}$ & $\begin{array}{c}\text { Input Non } \\
\text { Tradable }\end{array}$ & \\
\hline $\begin{array}{l}\text { Harga } \\
\text { Privat }\end{array}$ & A & B & $\mathrm{C}$ & $\mathrm{D}$ \\
\hline $\begin{array}{l}\text { Harga } \\
\text { Sosial }\end{array}$ & $\mathrm{E}$ & $\mathrm{F}$ & $\mathrm{G}$ & $\mathrm{H}$ \\
\hline Divergensi & $\mathrm{I}$ & $\mathrm{J}$ & $\mathrm{K}$ & $\mathrm{L}$ \\
\hline
\end{tabular}

Sumber : Monke and Pearson, 1989.

Keterangan :

a. Keuntungan Privat $(\mathrm{PP})$ atau $\mathrm{D}=\mathrm{A}-\mathrm{B}-\mathrm{C}$

b. Keuntungan Sosial (SP) atau $\mathrm{H}=\mathrm{E}-\mathrm{F}-\mathrm{G}$

c. Keunggulan Komparatif $(D R C R)=G /(E-F)$

d. Keunggulan Kompetitif $(\mathrm{PCR})=\mathrm{C} /(\mathrm{A}-\mathrm{B})$

e. Transfer Input (IT) $=\mathrm{J}=\mathrm{B}-\mathrm{F}$

f. Transfer Faktor $(\mathrm{FT})=\mathrm{K}=\mathrm{C}-\mathrm{G}$

g. Koefisien Proteksi Nominal Input yang Diperdagangkan $(\mathrm{NPCI})=\mathrm{B} / \mathrm{F}$

h. Transfer Output $(\mathrm{OT})=\mathrm{I}=\mathrm{A}-\mathrm{E}$

i. Koefisien Proteksi Nominal Output (NPCO) $=\mathrm{A} / \mathrm{E}$

j. $\quad$ Transfer Bersih (NT) $=\mathrm{L}=\mathrm{D}-\mathrm{H}$

k. Koefisien Keuntungan $(\mathrm{PC})=\mathrm{D} / \mathrm{H}$

1. Koefisien Proteksi Efektif $(\mathrm{EPC})=(\mathrm{A}-\mathrm{B}) /$ (E-F)

m. Rasio Subsidi Produsen $($ SRP $)=$ L $/$ E

Catatan :

$\mathrm{A}=$ Penerimaan privat, yaitu produksi dikali kan harga pasar $(\mathrm{Rp})$

$\mathrm{B}=$ Input tradable dikalikan dengan harga pasar (Rp)

$\mathrm{C}=$ Input nontradable dikali harga pasar (Rp)

$\mathrm{D}=$ Keuntungan privat $(\mathrm{A}-(\mathrm{B}+\mathrm{C}), \ldots(\mathrm{Rp})$

$\mathrm{E}=$ Penerimaan sosial, yaitu produksi dikalikan dengan harga sosial (Rp)

$\mathrm{F}=$ Input tradable dikalikan harga sosial $(\mathrm{Rp})$

$\mathrm{G}=$ Input nontradable dikali harga sosial $(\mathrm{Rp})$

$\mathrm{H}=$ Keuntungan sosial $(\mathrm{E}-(\mathrm{F}+\mathrm{G}), \ldots(\mathrm{Rp})$

\section{HASIL DAN PEMBAHASAN}

Indikator PAM (Policy Analysis Matrix) berasal dari data hasil kuisioner yang diajukan pada peternak. Data tersebut berisi data penerimaan peternak (output), biaya produksi (input tradable dan input non tradable) yang terbagi berdasarkan harga privat (aktual) dan harga sosial (harga bayangan).

Data output input pada harga privat dimasukkan pada matrik PAM baris pertama sedangkan data output input pada harga sosial dimasukkan pada matrik PAM baris kedua. Setelah dua baris matriks PAM terisi, akan diperoleh keuntungan privat, keuntungan sosial, transfer output transfer input, dan transfer bersih. Hasil dari analisis PAM tersebut dapat dilihat pada Tabel 2.

Sel pada baris pertama yaitu sel A adalah penerimaan peternak satu periode yaitu 35 hari sebesar $R p$ 295.512.501 yang dihitung berdasarkan harga jual ayam yang diterima peternak dari pedagang besar/ mitra yg bekerjasama dengan peternak. Sel B yaitu biaya input tradable (input yang diperdagangkan di pasar internasional yang keluarkan untuk sebesar Rp 4.329.231 untuk setiap satu periode ayam ras pedaging

Sel C merupakan input non tradable (input domestik yang tidak diperdagangkan di pasar internasional) yang harus dikeluarkan peternak untuk memproduksi satu periode (35 hari) ayam ras pedaging sebesar $\mathrm{Rp}$ 182.720.819.

Jumlah dari input tradable dan input non tradable merupakan biaya total input dalam memproduksi memproduksi satu periode (35 hari) ayam ras pedaging pada harga privat.

Tabel 2. Policy Analysis Matrix Usaha Ternak Ayam Ras Pedaging/ 8000 Ekor

\begin{tabular}{lllll}
\hline Komponen & Penerimaan & Input Tradable & Input Non Tradable & Keuntungan \\
\hline Harga Privat & 295.512 .501 & 4.329 .231 & 182.720 .819 & 108.462 .451 \\
Harga Sosial & 193.801 .861 & 2.286 .780 & 182.720 .819 & 8.794 .262 \\
Divergensi & 101.710 .640 & 2.042 .451 & 0 & 99.668 .189 \\
\hline
\end{tabular}

Sumber : Data Primer diolah, (2017) 
Jumlah tersebut menjadi faktor pengurang pada penerimaan peternak sehingga diperoleh keuntungan privat peternak (ditunjukkan pada sel D) sebesar Rp 108.462.451.

Sel pada baris kedua yaitu sel E merupakan penerimaan peternak satu periode (35 hari) ayam ras pedaging berdasarkan harga jual yang seharusnya diterima sesuai dengan harga ternak sejenis di pasar dunia Rp 193.801.861. Sel F yaitu biaya input tradable yang keluarkan untuk setiap satu periode (35 hari) ayam ras pedaging sebesar $\mathrm{Rp} 2.286 .780$.

Sel $G$ merupakan biaya input non tradable yang harus dikeluarkan peternak untuk memproduksi satu periode (35 hari) ayam ras pedaging sebesar Rp 182.720.819 karena input non tradable pada sel $\mathrm{G}$ tidak ada yang harus impor maka biaya pada sel $G$ sama dengan biaya pada sel C. Jumlah dari input tradable dan input non tradable merupakan biaya total input dalam memproduksi satu periode (35 hari) ayam ras pedaging pada harga sosial. Jumlah tersebut menjadi faktor pengurang pada penerimaan peternak sehingga diperoleh keuntungan peternak pada harga sosial (ditunjukkan pada sel H) sebesar Rp 8.794.262.

\section{Analisis Keunggulan Kompetitif}

Keunggulan kompetitif yang dimiliki usaha ternak ayam ras pedaging dapat dilihat berdasarkan indikator nilai Keuntungan Privat (PP) dan Rasio Biaya Privat (PCR). Nilai PP dan PCR pada usaha ternak ayam ras pedaging ditampilkan pada Tabel 3.

Tabel 3. Keuntungan Privat dan Rasio Biaya Privat Usaha Ternak Ayam Ras Pedaging

\begin{tabular}{lr}
\hline Indikator & Nilai \\
\hline Keuntungan Privat (PP) & 108.462 .451 \\
Rasio Biaya Privat (PCR) & 0,63 \\
\hline
\end{tabular}

Sumber : Data Primer diolah, (2017)

Keuntungan Privat pada Tabel 3 memiliki nilai positif sebesar $\mathrm{Rp} 108.462 .451$, artinya peternak memperoleh keuntungan dari usaha ternak ayam ras pedaging yang dijalankannya. Berdasarkan uraian tersebut, kegiatan usaha ternak ayam ras pedaging di Kecamatan Musuk secara finansial layak dijalankan karena memberikan keuntungan kepada peternak.

Rasio Biaya Privat (PCR) merupakan pembagian antara biaya input non tradable privat dengan selisih antara penerimaan privat dan biaya input tradable privat. Usaha ternak memiliki keunggulan kompetitif apabila memiliki nilai PCR <1. Artinya keuntungan yang diperoleh peternak > dibanding biaya input non tradable privatnya. Semakin kecil nilai PCR, maka keunggulan kompetitif yang dimiliki usaha ternak suatu komoditas semakin besar.

Berdasarkan Tabel 3. diperoleh nilai PCR 0,63 yang artinya usaha ternak ayam ras pedaging yang diusahakan oleh peternak memiliki keunggulan kompetitif, dimana peternak mampu membiayai faktor domestik pada harga privat dan peternak juga mampu bersaing dengan usaha ternak ayam ras pedaging di wilayah lain.

\section{Analisis Keunggulan Komparatif}

Keunggulan komparatif dapat digunakan untuk mengukur efisiensi usaha ternak berdasarkan analisis ekonomi. Indikator keunggulan komparatif usaha ternak diukur dari nilai Keuntungan Sosial (SP) dan Rasio Biaya Sumberdaya Domestik (DRCR). Nilai SP dan DRCR pada usaha ternak ayam ras pedaging diperjelas pada Tabel 4.

Tabel 4. Keuntungan Sosial dan Rasio Biaya Sumberdaya Domestik Usaha Ternak Ayam Ras Pedaging

\begin{tabular}{lr}
\hline Indikator & \multicolumn{1}{c}{ Nilai } \\
\hline Keuntungan Sosial (SP) & 8.794 .262 \\
Rasio Biaya Sumberdaya Domestik & 0,95 \\
(DRCR) & \\
\hline
\end{tabular}

Sumber : Data Primer diolah (2017)

Keuntungan Sosial pada Tabel 5. bernilai positif yaitu Rp 8.794.262. Hal tersebut menunjukkan usaha ternak yang dijalankan menguntungkan secara ekonomi (sosial). Usaha ternak ayam ras pedaging yang dijalankan oleh peternak tetap menguntungkan meskipun tidak ada kebijakan pemerintah dalam input maupun output, baik berupa subsidi maupun proteksi harga dan nilai tukar rupiah.

Rasio Biaya Sumberdaya Domestik (DRCR) merupakan indikator penilaian rasio antara input non tradable (biaya sumberdaya domestik) terhadap nilai tambah yang dihitung dalam harga sosial. Suatu komoditas memiliki keunggulan komparatif apabila memiliki nilai DRCR $<1$. Artinya keuntungan yang diperoleh 
peternak lebih besar dibanding biaya input non tradable sosialnya. Semakin kecil nilai DRCR, maka keunggulan komparatitif yang dimiliki usaha ternak suatu komoditas semakin besar dan semakin efisien secara ekonomi.

Usaha ternak di Kecamatan Musuk memiliki nilai DRCR 0,95 yang artinya Usaha ternak tersebut memiliki keunggulan komparatif, dengan kata lain peternak mampu membiayaifaktor domestik pada harga sosial dan efisien secara ekonomi. Meskipun tanpa bantuan dan intervensi pemerintah, usaha ternak ayam ras pedaging memiliki daya saing kompartif dan dapat bertahan di pasar persaingan sempurna.

\section{Analisis Kebijakan Pemerintah Terhadap Input}

Kebijakan input mengindikasikan jenis kebijakan yang diterapkan pemerintah serta pengaruhnya pada usaha ternak ayam ras pedaging di Kecamatan Musuk.

Tabel 5. Indikator Kebijakan Pemerintah terhadap Input pada Usaha Ternak Ayam Ras Pedaging

\begin{tabular}{|c|c|c|}
\hline Indikator & & Nilai \\
\hline Transfer Input (IT) & & 2.042 .451 \\
\hline $\begin{array}{l}\text { Koefisien Proteksi Input } \\
\text { (NPCI) }\end{array}$ & Nominal & 1,89 \\
\hline Transfer Faktor (FT) & & 0 \\
\hline
\end{tabular}

Sumber : Data Primer diolah (2017)

Nilai Transfer Input (IT) pada ayam ras pedaging menunjukkan nilai positif $\mathrm{Rp}$ 2.042.451. Angka ini menunjukkan tidak adanya kebijakan pemerintah pada input tradable sehingga merugikan peternak karena peternak membayar harga input tradable lebih besar dibanding harga input tradable di pasar internasional.

Koefisien Proteksi Input Nominal (NPCI) merupakan rasio yang mengukur IT. Rasio ini menunjukkan seberapa besar perbedaan antara harga dalam negeri dari input tradable dengan harga sosial. Apabila NPCI $>1$, artinya biaya input di dalam negeri lebih tinggi dibanding biaya input pada tingkat harga dunia. Sebaliknya, apabila NPCI $<1$, artinya biaya input domestik lebih rendah dibanding biaya input pada tingkat harga dunia. Nilai NPCI diperoleh >1 yaitu 1,89, walaupun dalam penelitian ini tanpa ada campur tangan dari pemerintah akan tetapi dalam hasil penilitian berupa nilai NPCI 1,89 maka pemerintah mampu menaikkan harga input tradable pada pasar domestik.

Divergensi dapat mempengaruhi harga input non tradable sehingga menyebabkan harga privat input non tradable berbeda dengan harga sosialnya dan menimbulkan Transfer Faktor (FT). Divergensi pada input non tradable dapat bernilai positif (adanya pajak atau transfer sumber daya keluar dari sistem usaha ternak) atau negatif (adanya subsidi atau transfer sumber daya ke dalam sistem usaha ternak).

Usaha ternak ayam ras pedaging memiliki nilai Transfer Faktor positif yaitu 0 (nol) artinya tidak ada kebijakan pemerintah pada input non tradable yang digunakan peternak. Hal ini terlihat dari harga privat input non tradable yang dibayar peternak sama dengan harga sosialnya.

\section{Analisis Kebijakan Pemerintah Terhadap Output}

Kebijakan output dianalisis dengan Transfer Output (Output Transfer atau OT), Koefisien Proteksi Output Nominal (Nominal Protection Coefficient on Output atau NPCO).

Tabel 6. Indikator Kebijakan Pemerintah terhadap Output Usaha Ternak Ayam Ras Pedaging

\begin{tabular}{lll}
\hline Indikator & Nilai \\
\hline Transfer Output (OT) & & 101.710 .640 \\
Koefisien Proteksi & Output & 1,52 \\
Nominal (NPCO) & & \\
\hline
\end{tabular}

Sumber : Data Primer diolah (2017)

Nilai OT positif menandakan adanya subsidi atau transfer sumber daya yang menambah keuntungan sistem usaha ternak. Sedangkan nilai OT negatif menandakan adanya pajak atau transfer sumber daya yang mengurangi keuntungan sistem usaha ternak. Pada pasar domestik, harga output ayam ras pedaging lebih rendah dibandingkan dengan harga output di pasar internasional yang dilihat dari nilai Transfer Output pada Tabel 6, yaitu $\mathrm{Rp}$ 101.710.640. Hal ini berarti penerimaan privat peternak lebih tinggi dibandingkan penerimaan yang seharusnya bila pasar tidak terdistorsi harga output berupa ayam, karena terdapat transfer output dari produsen ke tengkulak/ konsumen sebesar Rp 101.710.640. 
Koefisien Proteksi Output Nominal (NPCO) merupakan rasio yang mengukur transfer output. Rasio ini menunjukkan seberapa besar perbedaan antara harga privat dan harga sosial. Apabila NPCO >1, artinya harga domestik lebih tinggi dibanding harga impor atau ekspor dan sistem usaha ternak tersebut tengah menerima proteksi. Sebaliknya apabila NPCO $<1$, harga output domestik lebih rendah dibanding harga dunia, artinya harga domestik tengah di disproteksi.

Berdasarkan Tabel 6, usaha ternak ayam ras pedaging memiliki Koefisien Proteksi Output Nominal $>1$ yaitu 1,52 artinya harga output domestik lebih tinggi dibanding output harga sosial, hal ini menandakan peternak seharusnya mendapatkan insentif dari pemerintah untuk meningkatkan/ memperbesar usaha ternaknya.

\section{Analisis Kebijakan Pemerintah Terhadap Input - Output}

Analisis kebijakan input-output digunakan untuk menganalisis kebijakan pemerintah terhadap input dan output sekaligus. Kebijakan input-output dianalisis dengan nilai Koefisien Proteksi Efektif (Effective Protection Coefficient atau EPC), Transfer Bersih (Net Transfer atau NT), Koefisien Keuntungan (Profitability Coefficient atau PC) dan Rasio Subsidi bagi Produsen (Subsidy Ratio to Producers atau SRP). Indikator - indikator tersebut tertera di Tabel 7.

Tabel 7. Indikator Kebijakan Pemerintah terhadap Input - Output Usaha Ternak Ayam Ras Pedaging

\begin{tabular}{lr}
\hline Indikator & \multicolumn{1}{l}{ Nilai } \\
\hline Koefisien Proteksi Efektif (EPC) & 1,52 \\
Transfer Bersih (NT) & 99.668 .189 \\
Koefisien Keuntungan (PC) & 12,33 \\
Rasio Subsidi Produsen (SRP) & 0,51 \\
\hline Sumber : Data Primer diolah (2017)
\end{tabular}

Tingkat Proteksi Efektif (EPC) merupakan rasio yang membandingkan nilai tambah pada tingkat harga domestik dengan nilai tambah pada tingkat harga dunia. Tujuan EPC adalah menunjukkan dampak transfer gabungan yang disebabkan sebuah kebijakan, baik transfer output tradable maupun input tradable. Apabila nilai EPC $>1$, artinya kebijakan terhadap harga output maupun subsidi terhadap input bermanfaat bagi peternak untuk terus mengembangkan usaha ternaknya. Sebaliknya apabila nilai EPC $<1$, artinya kebijakan pemerintah menghambat peternak untuk berproduksi.

Berdasarkan Tabel 7, usaha ternak ayam ras pedaging di Kecamatan Musuk memiliki nilai Koefisien Proteksi Efektif $>1$ yaitu 1,52 berarti kebijakan yang ada sekarang menguntungkan bagi peternak. Walaupun pada kondisi sekarang saat dilakukannya penelitian tidak ada kebijakan yang diterapkan di Kecamatan Musuk terkait usaha ternak ayam ras pedaging, tetapi menurut analisis $(1,52>1)$ hal ini menguntungkan bagi peternak walaupun tanpa adanya kebijakan dari pemerintah. Hubungan dengan pembahasan EPC yaitu kondisi dengan tidak ada kebijakan yang dialami sekarang menguntungkan namun peternak lebih merasa aman jika ada kebijakan.

Transfer Bersih (NT) merupakan penjumlahan dari seluruh dampak transfer, baik positif maupun negatif, baik penerimaan maupun biaya. Berdasarkan identitas keuntungan, Transfer Bersih merupakan penjumlahan dari OT, IT dan FT, sedangkan berdasarkan identitas divergensi, NT merupakan selisih antara keuntungan privat dengan keuntungan sosial. Nilai NT positif menunjukkan adanya tambahan surplus produsen, sebaliknya apabila nilai NT negatif menunjukkan berkurangnya keuntungan peternak akibat kebijakan yang diterapkan pemerintah tersebut.

Berdasarkan Tabel 7, diperoleh nilai Transfer Bersih yaitu positif Rp 99.668.189, Artinya adanya insentif ekonomi untuk meningkatkan produksi ayam ras pedaging, dilihat dari keuntungan yang diperoleh peternak ketika ada kebijakan dari pemerintah menjadi lebih tinggi dibandingkan kerugian apabila tidak ada campur tangan pemerintah.

Koefisien Keuntungan (PC) bertujuan mengukur dampak dari seluruh transfer atas keuntungan privat. Koefisien ini sama dengan rasio antara keuntungan privat dan keuntungan sosial yang dihitung dengan data yang sama dengan perhitungan NT. Nilai PC $<1$ menunjukkan keuntungan peternak lebih rendah dibanding keuntungan yang seharusnya diperoleh pada harga sosial. Sebaliknya nilai PC >1 menunjukkan keuntungan peternak lebih tinggi dibanding keuntungan pada harga sosial. 
Nilai Koefisien Keuntungan (PC) pada usaha ternak ayam ras pedaging sebesar 12,33 yang berarti keuntungan yang diterima peternak lebih tinggi dibanding keuntungan yang seharusnya diperoleh pada harga sosial. Dengan kondisi tidak adanya kebijakan pemerintah, keuntungan peternak lebih tinggi dibanding dengan keuntungan yang seharusnya peternak peroleh (berdasarkan harga sosial).

Rasio Subsidi Produsen (SRP) merupakan rasio yang digunakan untuk mengukur seluruh dampak transfer. Rasio ini menunjukkan sejauh mana penerimaan dari sistem meningkat atau menurun karena pengaruh transfer. Nilai SRP negatif menunjukkan kebijakan pemerintah yang diterapkan menyebabkn peternak mengeluarkan biaya produksi terhadap input lebih besar dibanding biaya imbangannya. Sebaliknya nilai SRP positif menunjukkan kebijakan pemerintah yang diterapkan menyebabkan peternak mengeluarkan biaya produksi terhadap input lebih rendah untuk berproduksi. Usaha ternak ayam ras pedaging memiliki nilai SRP positif 0,51 . Secara keseluruhan, terdapat 2 dampak akibat penerapan kebijakan pemerintah.

Penerapan kebijakan pemerintah berupa subsidi terhadap input tradable dan input non tradable menguntungkan peternak karena dapat mengurangi biaya produksi. Sedangkan kebijakan berupa distorsi harga output merugikan peternak karena mengurangi keuntungan peternak.

\section{KESIMPULAN}

Dari beberapa penjelasan didalam hasil dan pembahasan dapat disimpulkan usaha ternak ayam ras pedaging di Kecamatan Musuk memiliki nilai Private Cost Ratio (PCR) <1 yaitu 0,63 yang artinya sistem usaha ternak ayam ras pedaging yang diusahakan oleh peternak memiliki keunggulan kompetitif, diartikan selain mampu membiayai faktor domestik pada harga privat, peternak juga mampu bersaing dengan usaha ternak ayam ras pedaging diwilayah lain.

Selain memiliki keunggulan kompetitif usaha ternak ayam ras pedaging di Kecamatan Musuk juga memiliki nilai Domestic Resources Cost Ratio (DRCR) <1 yaitu 0,95 artinya sistem usaha ternak ayam ras pedaging yang diusahakan oleh peternak memiliki keunggulan komparatif, karena peternak mampu membiayai faktor domestik pada harga sosial dan efisien secara ekonomi.

\section{DAFTAR PUSTAKA}

Andala, A., Abidin, Z. dan Situmorang, S. 2014. Keunggulan Kompetitif dan Komparatif Usahatani Manggis di Kabupaten Tanggamus. JIIA, 2(3): 214 222.

Dhiany, S.A. 2008. Analisis Daya Saing Usaha Tani Mangga Gedong Gincu (Mangifera indica L.) Kasus di Desa Sliyeg Lor, Kecamatan Sliyeg, Kabupaten Indramayu, Jawa Barat. Skripsi. Program Eksistensi Manajemen Agribisnis. Fakultas Pertanian. Institut Pertanian Bogor.

Setiawan, K., Hartono, S. dan Suryantini, A. 2014. Analisis Daya Saing Komoditas Kelapa Di Kabupaten Kupang. Agritech, 34 (1): 88 - 93.

Monke, E.A. dan Pearson, S.R .1989. The Policy Analysis Matrix for Agricultural Development. Cornell University Press. Ithaca.

Monke, E.A. dan Pearson, S.R. 1995. The Policy Analysis Matrix for Agricultural Development. Cornell University Press. Ithaca.

Pearson, Scott. 2005. Aplikasi Policy Analysis Matrix pada Pertanian Indonesia. Yayasan Obor Indonesia. Jakarta.

Sugiyono. 2002. Metode Penelitian Kuantitatif Kualitatif dan RND. Alfabeta. Bandung.

Sugiyono. 2010. Metode Penelitian Kuantitatif Kualitatif dan RND. Alfabeta. Bandung.

Sugiyono. 2011. Metode Penelitian Kuantitatif Kualitatif \& RND. Alfabeta. Bandung.

Sugiyono. 2012. Memahami Penelitian Kualitatif. Alfabeta. Bandung. 